awarded in or about May, 1855, ) being anxious to know the fate of his essay, wrote to the Dublin Medical Press, requesting the Editor would announce whether the prizes were given away. No notice being taken of the communication, I wrote to the Secretary of the College of Surgeons, stating that the writer was one of the essayists, and requested the Secretary would inform the profession what was done with the prizes, as, if the prizes were not to be distributed, the essayist wished to get back his essay. No notice being taken of this communication either, I am in doubt what to do, for, as may be supposed, a candidate for a prize would not like to have his name known.

Candidates were requested to send in their essays by the Ist of February, 1855. This was done by me, and since that time, now over twelve months, I have not heard what has become of the money or of my essay. Under such circumstances, I take the liberty of making the matter public through your worldknown journal. I of course conceal my name, but announce myself as

Dublin, April, 1856.
ONE OF THF CANDIDATES For THE Carmichael Prizes.

\section{MEDICATED COD-LIVER OIL}

To the Editor of THe LANCET.

SIR, - In reply to Mr. Barnes's letter in your last number, I can assure him that he need not be under any apprehension that I shall claim, or have claimed, the merit of having first effected every possible combination of cod-liver oil. In truth, so far from denying or hiding the fact that Mr. Barnes had dissolved biniodide of mercury in cod-liver oil, I pointed out this circumstance to those most deeply interested in securing the exclusive privilege of manufacturing the preparations patented by Mr. Horsley, as an evidence additional to mine of the in validity of his patent.

When the extreme dissimilarity between the characters and properties of an alkaloid and a metallic compound is considered, I certainly am surprised that an intelligent chemist like $\mathrm{Mr}$. Barnes should have imagined that his announcement of the fact that biniodide of mercury was solnble in cod-liver oil led me to the discovery that other substances were soluble in codliver oil. The latter being information well known before $\mathrm{Mr}$. Barnes's annonncement.

If there be any credit due to me for having first discovered such preparations as cod-liver oil with quinine, iodide of iron, \&c., I certainly cannot give any of that credit to Mr. Barnes, for I am indebted to the highly-suggestive work on "Physiological Chemistry," by Lehmann, for the idea that such preparations wrould prove valnable in medicine; and in carrying that idea to a practical conclusion, 1 do not think that any person conversant with chemistry will consider that I could receive any light from Mr. Barnes's paper.

I am, Sir, your obedient servant,

Brook-street, April, 1856.

WM. BASTICK.

\section{To the Editor of THE LANCET.}

SrR, - During my residence at the University College Hospital as dispenser, I well remember dissolving phosphorus in cod-liver oil, according to a prescription ordered by one of the medical stafi.

There were several patients taking the phosphorus and oil for a length of time, (to the best of my recollection in the year 1849 or 1850 , certainly not later than June, 1851.) Mr. Bastick and Mr. Barnes have, therefore, no claim for priority of invention of " melicated cod-liver oil," it having been used in haspital practice some years before the date "October, 1853," as given by Mr. Barnes in your last impression.

Turnsfield, Apri], 1856 I am, Sir, your obedient servant,

W. H. SWANN.

\section{THE EMPRESS AND THE PAUPER.-HATSTEAD UNION.}

To the Ealitor of THE LANoET.

Srn,-It has been circulated in the public papers, that M. Dubois received 30,000 francs for attending the Empress in her accouchement, and that the other medical attendants were proportionately liberally paid. "Sic parvis componere magna!" I will relate a case very similar in its nature in all except the remuneration.

In my capacity of acting medical officer to this nnion, I was called, a month ago, to attend the wife of James $\mathrm{T}-$, a labourer residing at Toppesfield, six miles from my residence,

who was stated to have been in labour three days-that is, she had had a Mrs. Hall, an experienced midwife, with her two days and three nights, and that she said I must come directly. I sent the husband to the relieving officer for an order. $\mathrm{He}$ refused it. I then wrote the said official an note, requesting an order, and sent it by the husband, at the same time giving the man my instruments.

On my arrival, I found that it was the first child, the mother's age about thirty-three or thirty-four, and the head was firmly impacted in the pelvis. The husband arrived about half an hour after myself, but brought no order. Meanwhile, I despatched a message for some brandy, to the inn, some mile and a half distant, and after a short time, by the aid of the forceps, I introduced the "little stranger" to this world of trouble. He was plump, and, after a little stimulus, very lively. Though not a Roi d'Algerie, he resembled his august majesty by retaining for a short period unmistalkable evidence of the difficulty of his admission into society; and here the comparison ends.

I applied to the board of guardians to give me an order for attending this case, and it was, after due deliberation, refused, and the only chance of remuneration remains to be extracted from the pocket of a humble and hardworkirg man, who has to maintain a wife and child out of ten shillings per week. Further comment is superfluous.

Malstead, April, $18 \tilde{6} 6$. I am, Sir, yours, \&c.,

\title{
GRIEVANCES OF POOR-LAW SURGEONS.
}

AT a meeting of the Medical Officers of the Manchester Union, it was unanimously resolved, -

1st. -.'That this meeting, being duly impressed with the deficient remuneration of Union surgeons generally, and the want of an examination of the districts, as recommended by the Committee of the House of Commons of 1854, views with pleasure the movement for effecting these objects.

2nd. - That the Medical Officers of this Union hereby form themselves into an association for the promotion of this movement.

3rd. - That this meeting believes that the best method of carrying out the above views will be by the presentation of $a_{4}$ petition to Parliament as soon as possible; and that the members for the city of Manchester and connty of Lancaster be requested to support its prayer.

4th. - That Mr. Armstrong be appointed local secretary and treasurer.

5th. - That a subscription of $5 s$. each be entered into and forwarded at once to Mr. Griffin; to be repeated quarterly if necessary.

6th.-That a small subscription be likewise made for incidental expenses.

7th. - That the best thanks of this meeting are due, and are hereby given, to R. Griffin, Esq., for his exertions on behalf of Union surgeons
(Signed)
John Armstrong, Local Secretary.

At a meeting of the Medical Officers of the Gateshead Poorlaw Union, held on the $22 \mathrm{nd}$ ultimo, pursuant to notice, the following resolutions were passed:-

1st.-. That the Medical Officers of this Union do send in their ad hesion to the movement now originated by Mr. Griffn, of Weymouth, for the better regulation of medical relief to the poor, and do promise their co-operation as regards the general principle of the movement.

2nd. - That the Medical Officers of this Union do form a committee, and that Mr. Wilson be nominated secretary, with power to receive a small subscription to pay the incidental expenses. (Signed)

Pozeret Davis. JOHN CALTENDER. HENRY DOND.

Gateshead, March 22nd, $185 \tilde{6}$.

At a meeting of the Medical Officers of the Bideford Union, held on the 25 th ultimo, at Bideford, it was resolved unanimously, -

1st. - That this meeting begs to acknowledge its obligations to Mr. Griffin for his efforts to improve the present inadequate amount of remuneration of the Union Medical Officers.

2nd. - That this meeting pledges itself to support Mr. Griffin in his laudable undertaling; and that a subscription of $5 s$. per
J. H. StTephenson. R. H. WILSON. JOHN M`AlLUM. 